\title{
NEW PARADIGM OF ADMINISTRATIVE COURT IN MODERN GOVERNANCE
}

\author{
Aju Putrijanti (Author) \\ Faculty of Law, Diponegoro University, Semarang \\ Semarang, Indonesia \\ E-mail : aputriyanti@yahoo.com
}

\begin{abstract}
The development of governance had been influenced the Administrative Court as a judiciary system which had specific competence. In the modern governance, the implementation of government's act is more complicated, economy and political issues, fast changing of social norms and information technology also give the powerful impact. Administrative Court has an authority to investigate, decide and settle the administrative dispute. Administrative Court has to protect the civil rights from the abuse of government's act. The issue is how the new paradigm of administrative court should be built in modern governance to protect civil rights and access to justice for the citizenship. The method is using normative and comparison approach. The results is new paradigm of Administrative Court is needed because it has to maintain the government's act as modern governance, access to justice and protect civil rights. The new paradigm must also accomodate the modern court as an effort to adjust with modern governance. Conclusion is Administrative Court has to move to new paradigm in order to supervise the government's act, protect the civil rights and access to justice.
\end{abstract}

\section{Keywords : New Paradigm, Administrative Court, Modern Governance}

\section{INTRODUCTION (HEADING 1)}

In State Law, all the government's act should be based on regulations, acts. The government has the power of authority to regulates and command. The implementation of governance's act, should be supervised and could be done by internal or external body. The Administrative Court (herein after will be called as The Court) is the external supervision with spesific competence in administrative disputes.

The development in information technology has a great impact to our life and globalization, modernization becomes a part of our life. The dynamic development has to follow with the proper and right regulations, clear substance of regulations and behaviour of society to obey the regulations. In implement the regulations, sometimes there will be disputes between the government and the people, and settle in the Court.

The government's act, the globalization and modernization, the people and the Court are connected to build the country and the role of the Court as external supervisor is to supervise the government's act and protect the human rights. The role of the Court will be broadened and will be easier for the people to get access to justice. The paradigm of governance had been shift from the ordinary to modern governance, considering the recent developments.

From the above description, the issue is how the new paradigm of administrative court should be built in modern governance to protect civil rights and access to justice for the citizenship.

\section{METHODS}

To solve the problem is using yuridically normative and comparison approach. Normative approach is by analyzed the actual regulations related with the Court, also references. Comparison approach is to know the regulation in some country related with the Court and the adjusment to the changes.

\section{RESULT AND DISCUSSIONS}

\section{A. Existing Condition of Administrative Court}

Indonesia is a State Law based on The Constitution of 1945 and the implementation the government's act should be based on law. Supreme Court is the highest judiciary body with the 4 (four) judiciary bodies below the supervision of the Supreme Court. The Court formed based on Law No 5 Year 1986 of Administrative Court which has an authority to investigate, decide and settle administrative disputes, between government and the people or private body and law enforcement in administrative law.

Law No 5 Year 1986 as a legal basis to build an administrative court as one judiciary body below the Supreme Court. The existence of the Court in State Law is important, because as a judicial control against government's act, protect the human rights, give justice by settle the administrative disputes. Judicial control against government's act are external control, represive

As there were 4 (four) amendments of the Constitution of 1945 , the regulations of the Court followed the amendments, the first amendments of the regulation was Law No 9 Year 2004, the second was Law No 51 Year 2009. Both amendments highlighted the execution of judge's verdict which still became a problems of law enforcement in 
administrative law. Substantially, both amendments did not gave a new procedural according to the Court.

In the Law No 5 Year 1986 some substances were adopted from Dutch Administration Law, which can be understood was to make efficient because of the lack of material substances to made a new regulations, on the otherside this also could not fulfilled and fit with real circumstances. At the beginning of making the Law No 5 Year 1986 of Administrative Court there were a few of information, sources, so the government had been sent judges to France, Dutch to learnt and got more info of the Court, and by comparison study for better regulations.

In the early year of the Court, was settled administrative dispute in narrowly way, because only the meaning of decree which was sued to the Court.(1) Most of the people did not know the important and the existence of the Court, there were no doubt about it. The disputes were about the employee affair, land certificate, it was very limited and not vary as today.

Started from the 1990's, the disputes were become vary, such as auction, forestry, the Commitee of Public Information, the infringement of administration election, local election, merk, housing, education, tax, brand, private law and many other. The increased of lawsuit to The Court was indicate of public awareness in administrative law enforcement that people know their rights as citizen in civil right.

The existing condition of the Court is important and needed for some reasons since there are the complexity of government's duty, type of duty become more vary, the relationship between the government and the people should be regulated strictly so each party knows their rights and duty, to build law certainty for the implementation of government's duty.(2) The function of the Court might be shifting, and nowadays this is a challenge to adjust and settle the disputes based on the positive laws.

\section{B. The new paradigm of Administrative Courts}

The changing of politics, economics, information technology as a part of human being has been shift to a new paradigm is called $\mathrm{e}-$ governance. E-governance means that to serve the public, the government using the development of information technology to make the affairs such as permission become faster, easier, transparent. Government using the newly application style to modernize all the affairs and supports with clear budget, human resources ability, build the infrastructures include hard and soft skill. On the other side, this will educate people to use the development of information technology and reuse of environment, since the environment has become a important topic globally.

The globalization means that the current development in every sector becomes borderless or it is very easy to get know what is happen on the other side of the continent by clicking the button of the smartphone either computer. That is a benefit the development of information technology, without going far away, we can know everything rapidly in an easy way. There is a strong relations between globalization and development of information technology, as we can ignore it, since this become a present of our activities. In the era of globalization, the needs of any information against civilization and human prosperity has been highly enhanced and can not be denied.

(3)In some countries, the government already use the eprocedure, e- procurement, e-document in order to accept the innovation technology and re-use of environment.

As proposed by Setlur B.N. Prakash two type of court in global era, the concept of e - court and virtual court.(4) The e - court is real court with paperless but the virtual court, there will be no court hall, no time remaining, using the development of information technology for exchanges the documents, the use of digital signature and electronic documents for purposes. The proposed courts are totally using the modern technology but should be supported with right actions and regulations. The people should be well-informed of using the information technology, it is relates with the society education and culture. In England, they used hybrid type of e-court and conceptualized virtual court. The problems will not be the same for the each country.

There are 5 important points which are shaped the modern governance, as cited from Jinseop Jang, et.al, individual empowerment, increasing awareness of human security, institutional complexity, international power shift and liberal world political paradigm.(5) All the 5 (five) points as mentioned above, are important if we want to develop and follow the globalization. On the other side, it will be very strict to adjust with the social-life, politic, law enforcement and many important things in each state.

The advantages of using information technology in government's activity according to Ghazzawi Khalil are, first, the government had a chance to improve the efficiency and enhance the business processess for public administration and on the other hand, it will lead to give higher quality to consumer oriented; second, the possibility to involve the people and bussinesses to make a decision making processess as well as administrative process.(6) In welfare state the role of government to implement the regulations and developing the country needs cooperpation and contribution from private sector.To build the infrastructure and supporting sector to increase the quality in public service, it needs a clear regulations and legal certainty in law enforcement.

In Bangladesh, as cited from Sharif N. As-Saber, et.al, the country has been struggling from corruption, inefficient bureaucratic practice, political division tried to implement and improve to e-government for better relationship and transparencymight have the same problems as Bangladesh, with prior to give a good public service by using the development of information technology, but on the other hand, there is a lack of education, lack of economic, lack of accountability and many others which might be impede the government's plan to build the country.

The Law of Governance Administration made based on Pancasila and The Constitution of 1945, and law is formed according to the necessity of the society, it might differ to other state. It is important to know how the people react of the shifting paradigm in governance, since this is the new regulation in governance administration. To implementation of the regulations needs good hardskill, softskills from the 
government, society. In developing countries, the condition of people are vary from education, social economy, culture, habits. This is the reason why the developing countries needs a different and spesific regulations which can be accepted and applied in their conditions. (7)To fight the obstacles it will needs time, and must be supported from the government and stakeholder. People with lack of education, lack of socialeconomy should have a proper actions so they can follow the development of governance. Government has to prepare, support both the people and the development to achieve the nations goals.

New paradigm in government's duty started when the Law No 30 Year 2014 of Governance Administration has been passed. Law No 30 Year 2014 of Governance Administration (hereinafter is call Law of Governance Administration) which regulates and conduct the government's act such as the origin of authority, mandate, delegate, standard procedures, type of decree, the abuse of power, permission, administrative sanction, and many more and as material law to the Court. The new regulations not yet support with the related acts, it will make a new problems in administrative court justice system.

The explanation above make us consider that there is a shifting of paradigm in government's activity on their duty based on the regulations. The impact of the shifting paradigm is the shifting of government's public service, including the people's right to get access to justice. To supervise the government's public service is needs the role of administrative court which also has to make shifting in their role, broadened the authority, synzchronized the related regulations, remanage the administrative court justice system and this are the idea of the new paradigm of administrative court in modern governance. It also has a meaning that the role of Administrative Court not only the law enforcement of administrative law, but also build a good governance. The term of good governance might be vary in some country, but it has the meaning in universal, common understand, good governance refer to implementation of governance refer to transparency, accountability, rule of law,

The broadened authority is needed and important, because the type of government's act and disputes also vary, and can not be the same like previous. The development of society needs is the caused of variety in government's act, and State has an authority to regulates all the sectors. The development showed that government's act is vary and there is government's body which needed for the implementation of the State.There are disputes from this points and the society has rights to access to justice by put lawsuit to the court.

The ban of abuse of power is important to guide the government's officer in their duty. Governments are charges to do their authority in conscientious method, and should be based on regulations. Other government's body will check and give a record whether they make an abuse of power or not. It had been regulated in Law No 5 Year 1986 of Administrative Court in Article 53, but this already changed on the Law No 9 Year 2004 of Amendment of Law No 5 Year 1986 of Administrative Court. The type of ban of abuse of power in Law No 5 Year 1986 and Law No 30 Year 2014 were different. In the Law Of Governance Administration, the ban of abuse of power put the authority of government's officer or body side by side with the penal law, which should be divide properly.

The administrative court justsice system in modern governance needs to re-manage by considering the development of information technology and globalization. The government has to make an application which should be easy for everyone to fill in the application.To support the electronic system, the infrastrucutres has to be ready, and the capability of human resources also increase. The using of information technology to submitt the lawsuit may be consider for some reasons, but should be a new model that everyone has to learn and accept in a proper way.

The Supreme Court had been use the development of information technology to make easier to everyone to get info about progress of the case, their lawsuit and any information relates to the administrative court justice system. Transparency in judiciary system is important, because it is part of new paradigm of the Court and to build a good governance. Supandi said that the effort in transparency of information is a positive point and to fulfill the aim of independence of judiciary.(8) In general by some changes in judiciary system, it make more easier to people to get access of justice, it is important to get people know how about if they want to put lawsuit to the Court.

The demand of the society is the reformation in judiciary system, especially bureaucracy reformation. The main important thing in law enforcement, justice and bureaucracy reform is management, as the continuity of nation reformation.(9) This is the right time to re-manage the administrative court justice system, including the bureaucracy reform, case management, human resources development and using the technology information to build the system. All sectors are related and it must support to each other, otherwise the re-manage will be useless and the aims will not be fulfilled.

As comparison, Dutch judiciary system has been started the reformation since 1995 until today. The reformation was called New Public Management and they made the new judiciary organization act, also restructuring the judicial organization and the overall aims are to establish the judiciary as significant of social player in general trust of the public and respected by the political branches of government.(10) The reformation on judiciary organization is important, also considering the transparency and judicial independence which is always put in highlighted points in every judiciary body. The transparency, new model of public hearing and using the modern information technology become a requirement in modern governance.

The judge's role in settle dispute become broadened since the demands from society is increase especially in globalization era. In his article about the more responsives judges in Netherlands, M. De Hoon and S. Verbek introduce the changing role of judges, that judges involved the needs of litigants and decide, which method of dispute resolution would be appropriate and suitable solution for both parties, the methods comes from the judicial dispute resolution which the outcome is often stressed. (11) In this method, judge is 
demand to more active, it means that it is important to change the judge's thinking of his role, the fulfilled of human rights to get access to justice for everyone. From this method, it is possible there will be a new way of thinking in judge's mind.

To get access to justice in this era needs a new paradigm in the Court, and judge is one of the important point, because judge is in the administrative judiciary system. In some country they make some changes in their Judiciary Act as first step, and follow with the re-manage the administration court management system. The re-manage of administrative court system consider and base on some point, i.e. the system itself , is it easy for the litigants to understand the whole procedure, is it cost so much to get justice, is the actor in the system really understand their duty, what is the bottleneck in speeding the investigation of each case, is judge more responsive for the case, and many other questions might be .

The approach ten principles of court governance which are applicable to any court, advocated by Christine Durham and Don Becker, the principles reflect a general conclusion, are meant not as a rigid collection of rules, but as a starting point that can be adapted to fit with the needs of individual court systems, however those might be defined. (12) Basically ten principles as promoted by Durham and Becker, can be used in administrative court as a new paradigm. First principle is a well-defined governance structure for policy formulation and administration to entire court system, we can use this principle to build a legal structure and legal substance for administrative court. Commitment to transparency and accountable, is primarily in build a new paradigm of administrative court and as part of principles of good governance. Another principle is clearly established relationship among the government, stakeholder, board of judges, court administrators,commitee, should have a clear role which defined in regulations and each should obey precisely.

Since there is no border or limit acroos the nations, the law can be easily transform to become more helpful, understanding, applicable for those who needs. Judicial globalization has a meaning that describes a much more diverse and messy process of judicial interaction across, below, above borders,exchange ideas and cooperating in cases involving national as well as international.(13) In this context are involving "vertical relations" between national and international tribunal or judiciary, "horizontal relations" across national borders. The judge should develop a new model to follow the development cases as well as the interaction between judges, parties, government too, sits together and build a new model of judiciary system.

\section{CONCLUSSION}

The shifting paradigm of governance caused by globalization gave impact to implementation of government's duty as to give a good public services. The Administrative Court has to shift to new paradigm as it has role to supervise the government's act. New paradigm of Administrative Court has been starting since the Law No 30 Year 2014 legalized and the shifting paradigm comprises the broadened authority,

\footnotetext{
Identify applicable sponsor/s here. If no sponsors, delete this text box (sponsors).
}

synchronization of the related Acts, integrated administrative court justice system, which is important to support the government's duty.

Law No 30 Year 2014 of Governance Administration has broadened the authority of Administrative Court followed the vary of government's act, this also has to synchronized to regulations related with the Administrative Court. This new paradigm also has to followed by an integrated administrative court justice system, which gave respond and using the modern technology.

\section{References}

[1] Abdoellah P. Revitalisasi Kewenangan PTUN Gagasan Perluasan Kompetensi Peradilan Tata Usaha Negara. Yogyakarta: Cahaya Atma Pustaka; 2016. 45-47 p.

[2] Mawardi I. Paradigma Baru PTUN Respon Peradilan Administrasi Terhadap Demokratisasi. Yogyakarta: Thafa Media; 2016. 52-54 p.

[3] Supandi. To Anticipate Change of Law Paradigm As Result of Global Development. In: Essays And Commentaries On Indonesian Law. First Edit. Bandung: PT Alumni; 2017. p. 2.

[4] Prakash SBN. E Judiciary : a Step towards Modernization in Indian Legal System. J Educ Soc Policy. 2014;1(1):111-24.

[5] Jang J, Mcsparren J, Rashchupkina Y. Global governance : present and future. Palgrave Commun [Internet]. 2016;2. Available from: http://dx.doi.org/10.1057/palcomms.2015.45

[6] Khalil G. Processes for Environmental Policies. J Adm Sci Policy Stud. 2014;2(1):1-20.

[7] Basu S. E government and developing countries: an overview. Gov Inf Q [Internet]. 2004;27(2):109-32. Available from: http://onlinejournals.org/i-

/article/view/1887\%5Cnhttp://linkinghub.elsevier.com/retrieve/pii/S074 0624X07000044\%5Cnhttp://www.tandfonline.com/doi/abs/10.1002/itd j.20125\%5Cnhttp://www.tandfonline.com/doi/abs/10.1080/1360086041 0001674779\%5Cnhttp://linki

jac/article/view/1887\%5Cnhttp://linkinghub.elsevier.com/retrieve/pii/S074062 4X07000044\%5Cnhttp://www.tandfonline.com/doi/abs/10.1002/itdj.20 125\%5Cnhttp://www.tandfonline.com/doi/abs/10.1080/1360086041000 1674779\%5Cnhttp://linki

[8] Supandi. Judicature Competency Of Tata Usaha Negara To Resolve Conflict of Public Information. In: Essays And Commentaries On Indonesian Law. First Edit. Bandung: Alumni; 2017. p. 127.

[9] Supandi. Peran Pengadilan Sebagai Ujung Tombak Keadilan dan Kepastian Hukum dalam Penyelesaian Sengketa Berbisnis dalam Era Masyarakat Ekonomi ASEAN (MEA). In: Kapita Selekta Hukum Tata Usaha Negara. First Edit. Bandung: Alumni; 2016. p. 182-3.

[10] Langbroek P. Organization Development of the Dutch Judiciary, between Accountability and Judicial Independence. Int J Court Adm [Internet]. 2010;2(2):21-30. Available from: http://www.iacajournal.org/index.php/ijca/article/view/URN:NBN:NL: UI:10-1-115887

[11] de Hoon MW, Verberk S. Towards a more responsive judge: Challenges and opportunities. Utr Law Rev. 2014;10(4):27-40.

[12] Kimbrough CD, Herian MN, Rottman DB, Bornstein BH, Tomkins AJ. The Verdict Is In: Judge and Administrator Perceptions of State Court Governance. Justice Syst J. 2014;35(4):344-61.

[13] Slaughter A-M. Judicial Globalization. VA J Int Law. 2000;40:110324. 